\title{
NIETZSCHEAN TRANSVALUATION OF ESTABLISHED RELIGIOUS VALUES IN D.H. LAWRENCE'S THE MAN WHO DIED
}

Yeşim CARBAN*

\author{
ABSTRACT
}

One of the most influential English writers of twentieth century David Herbert Lawrence makes biblical allusions in his novella titled The Man Who Died. Lawrence casts aspersions on the doctrines of Christianity and raises doubts about Christians' established truths in the same way that German philospher and cultural critic Nietzsche does. That is to say, the main generic affinity which links Lawrence's novella to Nietzsche's theoretical postulations is their comparable outlook on religion. Both of these writers take an unconventional approach to Christianity by means of especially reevaluating Jesus Christ's teachings and sufferings. Furthermore, Lawrence goes as far as ancient Egyptian myths to dig deep into the roots of evil and enables us to analyse moral issues and makes us discover some of the reasons why immoral people or gods cause others to suffer. The events relating to morality in Lawrence's novel can be elucidated through Nietzschean notions, such as three spiritual phases symbolized by "the camel", "the lion", and "the child", "asceticism", "master vs slave morality", "ressentiment", "life and death" and "revenge". In spite of the fact that Nietzsche directs his criticisms particulary to Judaism and Christianity, Nietzschean notions can also be applied to religions like ancient Egyptian ones, which are explored by Lawrence in his novella.

Keywords: asceticism, Jesus Christ, Jews, life and death, morality, religion, ressentiment, revenge

\section{D.H. LAWRENCE'IN ÖLEN ADAM ADLI ESERINDE YERLEŞIK DİNI DEĞERLERIN NIETZSCHE ÜZERINNDEN YENIDEN DEĞERLENDİRILMESI}

$\ddot{O} Z$

Yirminci yüzyllın en etkileyici Ingiliz yazarlarından biri olan David Herbert Lawrence Ölen Adam isimli kısa romanında İncil'e göndermeler yapar. Lawrence temel Hristiyanlık öğretilerinin sert bir șekilde eleștirisini yaparken ve Hristiyanların yerleșik doğrularına șüpheci bir tavırla yaklaşırken, Alman filozof ve kültür eleştirmeni Friedrich Nietzsche'nin düşünce sistemine yaklașır. Bir diğer deyișle, Lawrence'ın kısa romanının, Nietzsche'nin konseptleriyle ilişkilendirilmesini sağlayan temel bağ, her ikisinin de dine karşı görüsslerinin karşılaştırılabilir olmasına dayanmaktadır. Her iki yazar da özellikle İsa Mesih'in öğretilerini ve çilelerini tekrar yorumlayarak, Hristiyanlığa karșı, kendi dönemlerinde geleneksel olmayan bakış açıları geliștirmişlerdir. Lawrence, antik Mısır mitlerine kadar giderek kötülüğün kökenine kadar inmeyi hedeflemiş; bu sayede, ahlaki konuları analiz etmemize ve kimi insanların ya da tanrıların neden diğerlerine acı çektirme arzusu duyduklarını keşfetmemize olanak sağlamıștır. Lawrence'ın kısa romanında geçen ahlak ile ilintili olaylar, Nietzsche'nin kimi nosyonları vasıtasıly irdelenebilir; örneğin, "deve", "aslan" ve "çocuk" kavramları ile sembolize edilen üçlü ruhsal evre, "çilecilik", "efendi- köle ahlakı", "hınç", "yaşam ve ölüm" ve "intikam". Nietzsche eleştirilerini direkt olarak Yahudilik ve Hristiyanlığa yöneltse dahi, kendisine ait kavramların, Lawrence'ın da eserinde incelediği üzere, eski Mısır dinlerine bile uyarlanması mümkündür.

Anahtar Sözcükler: ahlak, çilecilik, din, hınç, intikam, İsa Mesih, Yahudi, yaşam ve ölüm.

\footnotetext{
* Doktora Öğrencisi, Yeditepe Üniversitesi, Sosyal Bilimler Enstitüsü, İngiliz Dili ve Edebiyatı Doktora Programı, ycarban@dogus.edu.tr, ORCID: 0000-0002-8452-5247

FLSF (Felsefe ve Sosyal Bilimler Dergisi)

2021 Güz, sayı: 32, ss. 291-306

Makalenin geliș tarihi: 28.08 .2021

Makalenin kabul tarihi: 08.11.2021

Web: https://dergipark.org.tr/tr/pub/flsf Autumn 2021, issue: 32, pp.: 291-306 Submission Date: 28 August 2021 ISSN 2618-5784
} 
NIETZSCHEAN TRANSVALUATION OF ESTABLISHED RELIGIOUS VALUES IN D.H. LAWRENCE'S

THE MAN WHO DIED

Yeşim CARBAN

\section{Introduction}

A paper which synthesizes ideas belonging to Nietzsche and Lawrence is supposed to devote itself to religion, and so is this study. So as to find a perfect harmony between these writers' ideas, their reconcilable statements on religion are to be explored. D.H. Lawrence in his novella The Man Who Died creates two gripping narratives, while one of which has reference to Jesus Christ, the other one is pertinent to an ancient Egyptian religion about the clashes among the gods named Osiris, Seth, Horus and the goddess Isis. In the first part of the novella, readers are to reflect on the probability with regard to what if Jesus were raised from the dead today, imagining whether he would defend the same values due to which he was crucified or he would believe and act differently. In the second part, on the other hand, another resurrected man, the ancient Egyptian god Osiris, who was brutally murdered by his brother Seth, agonizes over whether life is worth living despite the fact that it is heavy with every kind of malice, through which readers are familiarized with Egyptian religious accounts of good and evil. By the same token, Nietzsche, in his various books, is quite enthusiastic when it comes to criticizing Judaism and Christianity and especially their most devoted members, priests. Throughout the paper, the objective is to represent manifold concepts of religion which are designated as sacred and indubitable by millions of believers in a different way, causing them to be revalued by means of Nietzsche and Lawrence's aesthetically pleasing and ground-breaking viewpoints.

In this short novel written by D.H. Lawrence, one of the main characters, the peasant has a lustrous rooster he has tied by the leg with a cord, which has caused the rooster to lose its clangour afterwards. Even if the cock is subjected to "the hollow chagrin of the cord round his leg"1, "its glancing of the eye of life, ever alert and watchful, overweening and cautious, and the voice of its life, crowing triumph and assertion"2 are in total disagreement with its subjection. While the cock was brooding over its enslavement, "on the same morning, a man awoke from a long sleep in which he was tied up." 3 He comes back from the dead, that is to say, the second protagonist is not only literally, but also figuratively a dead man who has lost his desire to exist. He comes to the peasant and his wife's house as a guest after rising from his tomb. One might assert that there is a crucial resemblance between the rooster and the dead man as to their both

1 David Herbert Lawrence, The Man Who Died, 2007, 8, Last Update: June 20,2020, http://gutenberg.net.au/ebooks07/0700631h.html

2 Lawrence, The Man Who Died, 8

3 Lawrence, The Man Who Died, 5 
feeling nauseous due to their existences' being regulated by the conditions which are not desirable to them. The dead man's loathing his body because of its showing even tiny signs of animation is so intense that Lawrence's descriptions enable readers to feel the dead man's extreme sadness as if this emotion were solid. When he resurrects, his lack of enthusiasm to exist manifests itself: "he resented already the fact of the strange, incalculable moving that had already taken place in him: the moving back into consciousness. He had not wished it. He had wanted to stay outside, in the place where even memory is stone dead." ${ }^{4} \mathrm{He}$ resists his state of being alive with all his strength and longs for lapsing into nullity, oblivion and unconsciousness of being dead; nevertheless, he has no other choice but to rise to his feet just like the rooster that has no other option other than remaining in its bondage.

\section{Three Metamorphoses of the Spirit}

In his philosophical novel Thus Spoke Zarathustra, Nietzsche refers to three metamorphoses of the spirit successively "a camel", "a lion" and "a child". The camel stands for "the weight-bearing spirit", since it kneels down just like camels do and wants to be well loaded with other people's truths, shalls or shan'ts. This spirit then becomes a lion and starts to have designs on fighting with his master who burdens him heavily. At this point, a parallel among these three spirits and the rooster and the dead man in the novel can be drawn. The rooster is not free and it longs for freedom from the domination caused by the peasant that is its master. Nietzsche also mentions another creature which is called "a dragon". Here, the peasant represents the dragon since the dragon might be likened to God or to the people who desire to establish dominion over others. The dragon implies rules, obligations or values imposed on public by society through the agency of customs. God or the dragon or the peasant in this case gives an authoritative command by saying "Thou shalt!" or "Thou shalt not!". In order to get rid of his chains, the lion must struggle, which is also exemplified in the cock's making attempts so as not to be corded. When the rooster was tied by his leg, his "body, soul and spirit were tied by that string." ${ }^{5}$ As Nietzsche explicates, we need the lion "to create itself freedom, and give a holy 'No' even to duty." 6 The dragon restrains the lion from its having self-mastery, which is quite similar to the peasant's approach toward the poor rooster.

\footnotetext{
${ }^{4}$ Lawrence, The Man Who Died, 5

5 Lawrence, The Man Who Died, 4

${ }^{6}$ Friedrich Nietzsche, Thus Spoke Zarathustra, ed. Bill Chapko, 2010, 25, Last Update: Haziran 20, 2020, https://www.feedbooks.com/book/172/thus-spake-zarathustra
} 
D. H. Lawrence wrote to his close friend Earl Brewster, who was an American painter, and confessed the reasons which led him to create this novella which is also called The Escaped Cock: "I wrote a story of the Resurrection, where Jesus gets up and feels very sick about everything, and can't stand the old crowd any more - so cuts out - and as he heals up, he begins to find what an astonishing place the phenomenal world is, far more marvellous than any salvation or heaven - and thanks his stars he needn't have a 'mission' any more."7 Therefore, the dead man in the novella alludes to Jesus Christ. The dead man says "I gave more than I took, and that also is woe and vanity. So Pilate (Roman procurator of Judea who ordered that Jesus be crucified) and the high priests saved me from my own excessive salvation." 8 By means of death, Jesus did not only deliver from sins, but also he set free from everything including his faith, his endless selfsacrifice, "his excess," 9 his duty, and his mission; he reached his ultimate rest and relief. However, it also suggests Nietzsche's last spirit "the child", since the child symbolizes "innocence, and forgetting, a new beginning, a game, a self-propelling wheel, a first movement, a sacred Yes." ${ }^{10}$ As the next step after that of the lion, the spirit who has emancipated from others' "shan'ts", needs to welcome his/her rebirth in the same way Lawrence describes Jesus' resurrection. Nietzsche resumes as follows: "For the game of creating, my brothers, a sacred "yes" to life is needed: the spirit now wills its own will; the one who had lost the world now attains its own world." 11

In the novella, the dead man who later comes back to life denotes purity, a new beginning, rebirth, reawakening, a light, freedom, a spring, a brand new outlook and new sentiments. He is actually happy not maybe with his resurrection but with his releasing from his former obligations and duties; he is satisfied with his rejuvenation. He does not only die but is reborn again: "Now I (the dead man) am glad it (public life) is over, and the day of my interference is done. The teacher and the saviour are dead in me; now I can go about my business, into my own single life."12 He holds that "(He) has not risen from the dead in order to seek death again." ${ }^{13}$ By way of his death, the dead man finds life. Since he is a child again which Nietzsche mentions, he gains new values by breaking away from the old ones which have been taught to him by his God.

7 Steve Finbow, “Chapter 5”, in Notes from the Sick Room, Vol.1, London: Repeater Books, 2017

${ }^{8}$ Lawrence, The Man Who Died, 10

${ }^{9}$ Lawrence, The Man Who Died, 11

10 Nietzsche, Thus Spoke Zarathustra, 26

11 Nietzsche, Thus Spoke Zarathustra, 26

12 Lawrence, The Man Who Died, 9

${ }^{13}$ Lawrence, The Man Who Died, 11 
Through stripping himself of his God's instructions and having the intention of finding his own ones, he proceeds to be an "Übermensch" which is the ultimate stage in terms of being a creator. He aims to acquire new meanings and rematch some notions with their new definitions again; this is exemplified in his new outlook on the body: "Risen from the dead, he had realised at last that the body, too, has its little life, and beyond that, the greater life. He was virgin, in recoil from the little, greedy life of the body. But now he knew that virginity is a form of greed; and that the body rises again to give and to take, to take and to give, ungreedily." ${ }^{14} \mathrm{He}$ becomes cognizant of the fact that asceticism as a religious lifestyle which entails abstention from all kinds of bodily pleasure is also immoderate; while priests intend to desist from the body which is seen as the source of temptation for sinful acts, they fall into the clutches of another form of greed.

\section{Christianity and Asceticism}

What is meant here is that Christianity is not actually a doctrine invented by Jesus Christ because Jesus was also a follower of his God; Jesus was regarded as God's incarnation on earth and he endeavoured to do whatever his God ordered him. What makes Jesus particularly important for Christianity and Christians is the fact that he mediated between God and the common people and conveyed God's messages to them. In Lawrence's story, after Jesus resurrects, he releases himself from his commitment to God and whatever God teaches him also loses its importance. Therefore Christ's regarding the body as something temporary or insignificant is replaced by his taking a more positive attitude to it. As Nietzsche suggests, body, contrary to what devoutly religious people believe, is not less valuable than soul:

"Truly, not in afterworlds and redemptive drops of blood, but in the body do they (godlike men) also believe most; and their own body is for them the thing-in-itself. But it is a sickly thing to them, and gladly would they get out of their skin. Therefore they listen to the preachers of death, and themselves preach afterworlds. Listen rather, my brothers, to the voice of the healthy body; it is a more honest and pure voice. More honestly and purely speaks the

\footnotetext{
14 Lawrence, The Man Who Died, 11
} 
healthy body, perfect and squared-off: it speaks of the meaning of the earth." 15

In the aforementioned quotation about virginity, Lawrence questions Jesus' understanding of God and asceticism. As Nietzsche has argued, one of the biggest lies which Jews and Christians have taught us is asceticism which involves refraining from all kinds of pleasures, but especially from sensual ones due to religious purposes. Severe self-discipline demanded by asceticism is a kind of knowledge which even Jesus of Nazareth acquired by having been taught by his God and Judaism which is chronologically earlier than Christianity. Nietzsche asserts that the idea about restraining oneself from indulging in worldly pleasures is derived from Jewish priests whose outlook on the body is an indication of their debasing life and maybe Jesus was one of their victims as an adherent of some doctrines in Judaism. If one follows other's values, one is bound to suffer, as exemplified in Jesus' anguish. According to Nietzsche, asceticism evokes suffering and it glorifies pain. In the introduction part of his Genealogy of Morality, it is maintained that 'The priests' remedy for human suffering is the ascetic ideal, the ideal of a human will turned utterly against itself, or self-abnegation for its own sake. Such an ideal seems to express a selfcontradiction in as much as we seem to encounter with it life operating against life." ${ }^{16}$ Ascetic ideals of priests have nothing to do with rejoicing life but degenerating it. Jesus' life also seems to give strength to this approach of austerity, since his birth was not "spoilt" by coitus.

\section{The Egyptian Goddess Isis' Story}

The second part of the novella The Man Who Died makes mention of the ancient Egyptian goddess Isis. Before delving into Lawrencian descriptions of Isis' predicaments in this short novel, it would be beneficial to write briefly about her relatives, since Isis' sufferings revolve around her kinsmen. Isis is the daughter of the earth god Geb and the sky goddess Nut. Her siblings are also deities named Osiris, Seth, and Nephthys. She gets married to her brother Osiris and they get a son whose name is Horus. Osiris is the god of afterlife, death and rebirth, vegetation and fertility in ancient Egyptian religion. The other Egyptian god Seth, Isis and Osiris' brother, due to his harbouring resentment against Osiris' being an esteemed god, makes plans to commit a harmful act and attempts

15 Nietzsche, Thus Spoke Zarathustra, 30

16 Friedrich Nietzsche, On the Genealogy of Morality, ed. Keith Ansell-Pearson, New York: Cambridge University Press, 1994, 7 
to take his brother Osiris' life so that he can be the only king of Egypt. It is also believed that Seth is a god of resentment, disorder and violence in ancient Egyptian religion. Due to the fact that Seth regards his brother and his sister's husband Osiris as the cause of his inferiority and frustration, he kills him. After trapping Osiris in a coffin which is made up of lead, Seth throws it into the Nile. However, Isis finds Osiris' dead body in his chest and because Isis is capable of restoring a dead person to life, Osiris is revived. When Isis brings Osiris back to Egypt, out of resentment, Seth kills him again and tears Osiris' body into small particles and scatters them far away. Isis, as a consequence of her alteration into a bird, gathers those missing pieces and becomes able to unite them as a whole body. As a result of Isis' wrapping his body up, Osiris turns into a mummy and becomes the king of the dead in the underworld.

\section{Master versus Slave Morality}

Isis bears resemblance to Jesus of Nazareth with regard to their both being magical healers, helping the miserable, curing the sick and their relatedness to awe-inspiring authorities like kingships, pharaohs and God. Just as Jesus resurrected, so Isis is known to restore the deceased Egyptians and her husband Osiris to life. Nonetheless, Isis', Osiris' and Jesus' lives are destined to be devastated by slave morality or slaves' outlook on life.

Slaves do not necessarily have to be slaves in real terms, which means that gods like Seth can also be driven by slave morality, since slave morality represents envy, pessimism, cynicism, weakness, stagnation, passivity, timidity, inertia, lassitude and ressentiment to others' success. Since ressentiment is also a psychological term, its medical definition gains significance here so as to comprehend how slave morality functions. Ressentiment refers to "deep-seated resentment, frustration, and hostility accompanied by a sense of being powerless to express these feelings directly." ${ }^{17}$ For Nietzsche, slaves (the word slave is used figuratively, not literally) are most likely to hold a grudge against their masters, which results from the slaves' inability to possess wealth, power, beauty, fearlessness, superiority, strength, determination, nobility and heroic features, unlike their masters. Instead of striving to have such assets as being strong, slaves sling mud at their masters and glorify whatever their masters renounce. Therefore, while strength is praised in master morality, it is regarded as evil in slave morality. Evil as a notion has started to represent the life the masters lead;

\footnotetext{
17 “Ressentiment," Last Update: August 20, 2021, https://www.merriamwebster.com/dictionary/ressentiment
} 
slaves have considered themselves good because they are not like the 'evil' masters. In the slaves' understanding, strength is conceived as something unfair, since they think we should be subservient not to our masters but to the only master God. Slave morality asserts that we are all equal and fragile creatures only before almighty God. Slave morality begins with Jews and Jews' dismissing the earth and earthly pleasures as the source of evil, as Nietzsche suggests in Beyond Good and Evil: "The Jews - a people 'born for slavery' as Tacitus and the entire ancient world say, 'the people chosen of all peoples' as they themselves say and think - the Jews have achieved that miraculous thing, an inversion of values, thanks to which life on earth has had a new and dangerous charm for several millennia: - their prophets melted together "rich," "godless," "evil," "violent," "sensual" and for the first time coined an insult out of the word "world." The significance of the Jewish people lies in this inversion of values (which includes using the word for "poor" as a synonym for "holy" and "friend"): the slave revolt in morality begins with the Jews." 18 On the other hand, Nietzsche suggests that noble types of men who adopt master morality are value creators and truth determiners; they do not gain their power or take approval from an all-powerful creature like God, they are self-reliant. They obey only themselves and their own desires.

In the Egyptian goddess Isis' story, as Lawrence mentions in his novella, the topic related to slaves' (or herds') ressentiment for the superior ones is broached. Jesus and Isis or Osiris symbolize master morality in their calling out yes to life, which is shown in their accomplishments, such as their offering a variety of assistances to particularly people in distress. However, Romans who put Jesus to death ${ }^{19}$ by nailing him to a cross and gods like Seth who content themselves with causing others to feel sorrow, just because the others think in a different way or the others have strength are typical examples of slave morality. Romans and Jews disapproved Jesus, since Jesus said no to Jews' doctrines. When Jesus declared he was the Messiah by fulfilling the messianic prophecies, neither the Jews nor the Romans believed in him. The leaders of the Jewish establishment and the Romans perceived that Jesus had the charisma which might have led the crowds to launch rebellions against Imperial Rome. ${ }^{20} \mathrm{He}$ started to be conceived by the Romans and the Jews "as in revolt against the

18 Friedrich Nietzsche, Beyond Good and Evil: Prelude to a Philosophy of the Future, ed. Rolf- Peter Horstmann \& Judith Norman, New York: Cambridge University Press, 2002, 84

19 "Romans are to blame for death of Jesus," Last Update: June 20, 2020, https://source.wustl.edu/2004/02/romans-are-to-blame-for-death-of-jesus/ 20 "Who killed Jesus?," Last Update: June 19,2020, https://www.bbc.co.uk/religion/religions/christianity/history/whokilledjesus_1.shtml 
established order" 21 which was dominant Judaism and its ruling class. For Nietzsche, Jesus was a "naysayer". Jesus did not desire to think in the same way as the Jews and created Christianity by refusing Judaism.

Nietzsche seemed to consider Christ as a representative of Übermensch, since the founding father of Christianity is the only true Christian; Jesus was superior in terms of his being an enthusiastic spokesman for his own virtues. Contrarily, the ones who follow his truths become slaves who are too lethargic to discover and pursue their truths but active enough to cling to another's. As an indication of their ressentiment, masses consisting of Jews reflected their feelings of failure or inferiority onto Jesus whom they regarded as a threatening force to Judaism. As Nietzsche also touches upon in his philosophical novel Thus Spoke Zarathustra, "Be on your guard against the good and just! They would rather crucify those who devise their own virtue - they hate the lonesome ones." 22

By the same token, slave morality creates an other and detests its own creation or its own perception about otherness. The Egyptian god Seth regards his brother as an other who needs to be eliminated, since slaves do not endeavour to gain power; they humiliate the powerful by means of abominable acts like murder, so that they aim to get rid of feelings of inferiority. Seth becomes the god of envy and chaos, and he does not spend efforts to be a god which has positive characteristics like Osiris who is known as "permanently benign, lively, potent and youthful." ${ }^{23}$ Seth's ressentiment finds expression in his murder of his brother. Seth's fierce jealousy becomes apparent when he witnesses his brother Osiris' life of robust vitality. Stimulated by slave morality, Seth thinks that Osiris is evil because he is strong, healthy and mighty and therefore Osiris is a kind of person who needs to be destroyed. Since Seth is not robust enough to defeat Osiris in a battlefield, he kills him although the details of the murder are obscure. ${ }^{24}$ Contrary to warriors, slaves want to be pitied and they fill with abhorrence when nobles like Jesus is passionate about creating his own values or gods like Osiris becomes preoccupied with himself and others' welfare. As a consequence, the interrelation between Osiris and his brother Seth is also

\footnotetext{
21 Friedrich Nietzsche, The Antichrist, trans. H. L. Mencken, California: CreateSpace Independent Publishing Platform, 2016, 120

22 Nietzsche, Thus Spoke Zarathustra, 55

23 Donald B. Redford, The Oxford Essential Guide to Egyptian Mythology, New York city: Berkley Publishing, 2003, 302-7.

${ }^{24}$ Glenn S. Holland, Gods in the Desert: Religions of the Ancient Near East, Vol.1, Maryland: Rowman \& Littlefield Publishers, 2009, 42
} 
NIETZSCHEAN TRANSVALUATION OF ESTABLISHED RELIGIOUS VALUES IN D.H. LAWRENCE'S

THE MAN WHO DIED

Yeşim CARBAN

manifested in the relations among Jesus Christ and the Roman authorities in his era.

\section{Life and Death}

As mentioned before, Lawrence separates his novella The Man Who died into two sections and in both parts he introduces dead men to readers; in other words, whereas in the first part of the novella "the man who died" refers to Jesus of Nazareth, in the second one, the person who is called "the man who died" is Isis' dead husband Osiris. Both parts, through their protagonists, the men who died, deliberate on the nature of the notions "life" and "death". In order to grasp how Osiris penetrates to the essence of these notions, his relation with his wife Isis is to be examined exhaustively. Lawrence regards Isis as "the woman of the pure search" 25 or "Isis Bereaved", since Isis still seeks to uncover information about where Osiris' missing body parts are. She needs to bring his fragments together to form a whole person. To her horror, his body remains incomplete without "the loins of the male Osiris" 26 although she succeeds in obtaining his heart, head, limbs and body over a long period of time. Isis has to find "the final clue to him" 27 for their reunion. Nonetheless, another prominent detail about their story lies in Osiris' missing region. Since their son Horus was conceived after his father's death, Isis must have found dead Osiris' male copulatory organ which would enable him to have procreative power to impregnate her.

One day, a stranger comes to the temple where Isis lives and with the help of the death wounds through his belly, Isis comes to realize that it is Osiris. Contrary to what can be expected, in Osiris and Isis' regathering after a long period of separation, readers can not see scenes of jubilation but of woe. The reason behind this is that Osiris is perfectly aware of the fact that a dead man cannot give satisfaction to a woman who is full of life. The chasm between opposing attributes of death and life is conspicuous; while death evokes a malady, sorrow, bygone days, passivity, finitude, abstinence and hopelessness, life is symbolic of hope, desire, insatiability of appetites, animation, and continuation. Osiris does not want to respond to Isis' longing for their reunion via sexual intercourse, since he thinks that he cannot make her feel the warmth of the sun on her skin through his touch; all he has is the coldness of death. Osiris, aka "the man who died" 28 conveys his feelings of anguish as follows while Isis

25 Lawrence, The Man Who Died, 22

26 Lawrence, The Man Who Died, 17

${ }^{27}$ Lawrence, The Man Who Died, 17

28 Lawrence, The Man Who Died, 22 
craves for lovemaking. Consequently, the great difference between life and death manifests itself:

"Dare I come into touch? For this is farther than death. I have dared to let them (men) lay hands on me and put me to death. But dare I come into this tender touch of life? Oh, this is harder... How sensitive and softly alive she (Isis) is, with a life so different from mine! How beautiful with a soft, strange courage, of life, so different from my courage of death! What a beautiful thing, like the heart of a rose, like the core of a flame. Ah! how terrible to fail her, or to trespass on her!... And she saw the ghost of the death in him as he stood there thin and stark before her, and suddenly she was terrified, and she felt robbed. She felt the shadow of the grey, grisly wing of death triumphant... For her again he felt desperate, faced by the demand of life, and burdened still by his death. ${ }^{29}$

Both Jesus and Osiris face the dilemma regarding whether death is a relief or life is fulfilling in spite of various difficulties it presents. Osiris, the man who died, observes the common world and "(sees) it still hostile"30; that's why he thinks spending time alone is more preferable than mingling with the crowd, since the crowd is full of people who are capable of murdering innocents like Osiris. "He (is) haunted by the fear of the outer world. He says to himself: If they (men) can, they will kill us."' 31 Osiris is in agony with regard to vices and crimes happening in the real world and so is Jesus Christ who is also "a man who died" in the first part of the novella. For a bizarre reason, according to Lawrence, Christ is not unhappy with being a dead person and his aloneness as a dead person in this phenomenal world. Just as Osiris "rises naked" 32 from his coffin, so Christ rises from his tomb. He feels relieved when he leaves the chaotic world behind. In the novella, Jesus gives a beatific smile to the world of which he is no longer the savior:

"I made a mistake. I understand that they executed me for preaching to them. Yet they could not finally execute me, for now I am risen in my own aloneness, and inherit the earth, since I lay no claim on it." 33

${ }^{29}$ Lawrence, The Man Who Died, 21-25

30 Lawrence, The Man Who Died, 23

${ }^{31}$ Lawrence, The Man Who Died, 24

32 Lawrence, The Man Who Died, 24

33 Lawrence, The Man Who Died, 13 
NIETZSCHEAN TRANSVALUATION OF ESTABLISHED RELIGIOUS VALUES IN D.H. LAWRENCE'S

THE MAN WHO DIED

Yeşim CARBAN

The critical question here must be related to the reasons why both Jesus and Osiris died. Nietzsche would have answered this question by saying that they died, actually, they were killed by "despisers of life" due to "the hatred of the good and just." 34 Both Jesus and Osiris are afraid of the world and people when they are alive; living is weary but who applies such negative characteristics like being weary to earth? The answer is simple: priests who belittle the earth but revere heaven which has nothing to do with goodness but which is one of their biggest delusions. As Nietzsche indicates, people who invent fables such as heaven and long for God are "sickly" ones. ${ }^{35}$ Just like Lawrence, Nietzsche believes that the reason why Jesus suffers to a great extent is because he can not attach enough significance to the earth and earthly pleasures and he places more than enough value on sacrificing himself for others. In Lawrence's novella, when Jesus resurrects, he realizes how long he has been enduring enormous physical and psychological pain for other people who are actually wicked but call themselves good and just. Jesus would have remained far from the good and just, had he lived longer. Nietzsche, in Thus Spoke Zarathustra, grieves over Jesus' dying too early, even too early to mature his ideas, also alluding to "life" and "death", which he understands only when there is not any time to live more:

"Believe it, my brothers! He (the Hebrew Jesus) died too early; he himself would have disavowed his doctrine had he attained to my age! Noble enough was he to disavow!... But he was still immature. Immaturely loves the youth, and immaturely also hates the man and earth. Confined and awkward are still his soul and the wings of his spirit. But in man there is more of the child than in the youth, and less of melancholy: better understands he about life and death. Free for death, and free in death; a holy Naysayer, when there is no longer time for Yes: thus understands he about death and life."36

At this point, it would be beneficial to analyze what Christianity and Judaism consider about life and death for the simple reason that the theme of life and death constitutes the core of Lawrence's novella. Romans executed Jesus of Nazareth and Jesus himself had no other choice but to offer himself to God in the Crucifixion. In Human, All too Human, Nietzsche expounds what were running through in Jews' and Romans' minds when the Roman governor Pontius Pilate decided on the execution of Jesus Christ in Jerusalem around the year 30 . Nietzsche assumes that Jesus was sacrificed, since somebody had to be the sinner

${ }^{34}$ Nietzsche, Thus Spoke Zarathustra, 62

35 Nietzsche, Thus Spoke Zarathustra, 30

${ }^{36}$ Nietzsche, Thus Spoke Zarathustra, 62 
and that person also needed to compensate for his fault of being the sinner and the chosen person was Jesus himself. While nailing Jesus to the cross, in Nietzsche's opinion, the Romans had these ideas on their minds: "'Behold, thou art the lamb that beareth the sins of God."'37 Jesus is just a lamb which has been slaughtered as an offering to God in return for all the evil committed by humankind so far.

As Nietzsche indicates in his book Antichrist, Jews and Christians have praised death by presenting the idea of afterworld. In Thus Spoke Zarathustra, he calls despisers of the earth and the body as "the sick and dying" who also "invented the heavenly world" 38 By means of regarding life and instincts of life "as sinful, as misleading and as full of temptation" 39 , adherents of these religions have turned their eyes to heaven. Priests have sought happiness in another existence which has come to be called as heaven because they have detested the ones who take great pleasure in living. Therefore, they have made suffering on earth sacred in order to find joy in an unprovable realm. Bizarrely, pious ones are fascinated by the existence of death and saddened by life.

\section{The Notion of Revenge}

The following discussion is to lay stress on the notion of revenge from Nietzsche's point of view and the notion will be applied to Osiris' myth. As stated earlier, the virgin goddess Isis becomes inseminated by her deceased husband Osiris and they give their son the name of Horus. After putting Osiris to death, Seth usurps the throne of Egypt. Nonetheless, Horus, in order to seize control of the throne, opposes his uncle Seth. Needless to say, the main incentive for Horus to challenge his uncle is to take vengeance. Although Horus defeats Seth more than once in various competitions, their violent conflict lasts for nearly eight years because of Seth's being favoured by the judge of the competitions and his cunning schemes. However, the rivalry results in Horus' inheriting the kingship. Consequently, Horus not only assumes control of the kingship but also takes revenge of his father Osiris who has been brutally murdered by Seth.

According to Nietzsche, the most dangerous form of revenge is priestly vengefulness and "the most entrenched priestly vengefulness" 40 is fitting for

37 Friedrich Nietzsche, Human, All Too Human, trans. Reginald J. Hollingdale, Vol.9, Cambridge: Cambridge University Press, 2005, 223

38 Nietzsche, Thus Spoke Zarathustra, 30

${ }^{39}$ Nietzsche, The Antichrist, 41

40 Nietzsche, On the Genealogy of Morality, 17 
priestly people. According to the aristocratic value equation, "good $=$ noble $=$ powerful $=$ beautiful $=$ happy $=$ blessed. ${ }^{\prime 41}$ The powerless Jewish priests hated aristocratic values and negated them by claiming that "only the poor, the powerless, the lowly are good; the suffering, the deprived, the sick, the ugly, are the only pious people, the only ones saved, salvation is for them alone... You rich, the noble and powerful, you are eternally wicked, cruel, lustful, insatiate, godless, you will also be eternally wretched, cursed and damned!" 42 By means of misleading people to believe in their false statements, the Jews had their revenge on the powerful ones.

Nietzsche believes that justice is revenge or vice versa; in justice there is punishment; in punishment there is desire to take revenge. Horus desired to take his father's vengeance but his methods of having revenge were utterly different from those followed by Seth. Horus, in his battle against Seth, chooses to follow aristocratic virtues and proves his being the more powerful one in the battlefield. Nietzsche expresses his admiration for warriors like Horus. However, Seth, because he was not competent enough to defeat his rival, like Jews reversed aristocratic values in a deceitful way, thought that powerful must be destroyed cunningly. Just as the Jews and the Romans mocked (Jesus was made to wear the crown of thorns which is a sign of his being mocked) and ended the life of Jesus Christ because they knew that Christianity might have been strong enough to surpass Judaism, so Seth attempted to ridicule Horus and murdered his brother Osiris because Seth was aware of the fact that they were strong enough to beat him.

\section{Conclusion}

All in all, Lawrence and Nietzsche, as two distinguished writers who have changed our understanding of some controversial topics like religion, distrusted everything that people never raised a doubt about their truthfulness. Throughout this paper, it has been shown that both writers question whether Jesus was happy and contended with his life and they think hypothetically about how Christ would have acted if he had come to the earth again. Nietzsche believes that Christ would have "recanted his teaching" had he lived longer, since he was too " inexperienced, immature, naive and even childish" 43 during his lifetime and Lawrence states that Christ suffered a lot while he lived and when he

41 Nietzsche, On the Genealogy of Morality, 17

42 Nietzsche, On the Genealogy of Morality, 17

43 Raymond Angelo Belliotti, Nietzsche's Will to Power: Eagles, Lions, and Serpents, Vol.1, Newcastle upon Tyne: Cambridge Scholars Publishing, 2017, 126 
NIETZSCHEAN TRANSVALUATION OF ESTABLISHED RELIGIOUS VALUES IN D.H. LAWRENCE'S

THE MAN WHO DIED

Yeşim CARBAN

resurrected, he understood the value of life and felt the taste of freedom after releasing himself from his commitments. Even before Jesus' birth, around 2400 BCE, an Egyptian god called Osiris was subjected to a cruel and inhumane treatment by his brother which can be comparable to the violent victimization Jesus Christ underwent during his crucifixion.

$\underline{305}$ 
NIETZSCHEAN TRANSVALUATION OF ESTABLISHED RELIGIOUS VALUES IN D.H. LAWRENCE'S

THE MAN WHO DIED

Yeşim CARBAN

\section{BIBLIOGRAPHY}

Belliotti, R. Angelo. Nietzsche's Will to Power: Eagles, Lions, and Serpents. Vol.1. Newcastle upon Tyne: Cambridge Scholars Publishing, 2017.

Finbow, Steve. Notes from the Sick Room. Vol.1. London: Repeater Books, 2017.

Holland, Glenn S. Gods in the Desert: Religions of the Ancient Near East. Vol.1. Maryland: Rowman \& Littlefield Publishers, 2009.

Nietzsche, Friedrich. On the Genealogy of Morality, ed. Keith Ansell-Pearson. New York: Cambridge University Press, 1994.

Nietzsche, Friedrich. Human, All Too Human, trans. R. J. Hollingdale. Vol.9. Cambridge: Cambridge University Press, 2005.

Nietzsche, Friedrich. Beyond Good and Evil: Prelude to a Philosophy of the Future. New Yok: Cambridge University Press, 2002.

Nietzsche, Friedrich. The Antichrist, trans. H. L. Mencken. California: CreateSpace Independent Publishing Platform, 2016.

Redford, Donald B. The Oxford Essential Guide to Egyptian Mythology. New York city: Berkley Publishing, 2003.

\section{INTERNET SOURCES}

Lawrence, David H. The Man Who Died, 2007. Last Update: June 20,2020. http://gutenberg.net.au/ebooks07/0700631h.html

Nietzsche, Friedrich. Thus Spoke Zarathustra, ed. Bill Chapko, 2010. Last Update: June 20, 2020. https://www.feedbooks.com/book/172/thus-spakezarathustra

“Ressentiment." Last Update: August 20, 2021. https://www.merriamwebster.com/dictionary/ressentiment

"Romans are to blame for death of Jesus." Last Update: June 20, 2020. https://source.wustl.edu/2004/02/romans-are-to-blame-for-death-of-jesus/

"Who killed Jesus?" Last Update: June 19,2020. https://www.bbc.co.uk/religion/religions/christianity/history/whokilledjesus _1.shtml 